\title{
PERSIAPAN DAN PENYUSUNAN BAHAN BAKU LOKAL UNTUK FORMULASI PAKAN IKAN
}

\author{
Kamaruddin*), Usman*), dan Abdul Malik Tangko*) \\ *) Balai Riset Perikanan Budidaya Air Payau, Maros
}

\begin{abstract}
ABSTRAK
Usaha budidaya ikan dalam keramba jaring apung masih mengandalkan pasok pakan alami berupa ikan rucah yang dapat mencapai 60\%-70\%dari total biaya produksi. Karena itu perlu pengadaan pakan buatan yang memenuhi persyaratan kebutuhan nutrisi bagi pembesaran ikan, baik makro maupun mikro nutrien diperlukan sebagai informasi dasar dalam upaya pengembangan pakan buatan. Terdapat banyak bahan baku lokal yang sangat potensial dijadikan bahan baku pakan, seperti: ikan rucah, rebon, kepala udang (limbah cold storage), tepung darah (limbah pemotongan hewan), dan tepung DOC (limbah penetasan ayam). Dari beberapa bahan baku tersebut telah dianalisis kandungan nutrisinya dan telah dilakukan uji kecernaan masing-masing bahan menunjukkan bahwa bahan tersebut dapat mensubstitusi bahan baku impor tepung ikan sebagai sumber protein hewani. Selain bahan hewani, juga telah dilakukan analisis kandungan nutrisi bahan nabati lokal, seperti pemanfaatan bungkil kelapa sawit, bungkil kopra, dan dedak halus. Untuk menghasilkan pakan yang berkualitas, maka semua bahan harus dalam bentuk tepung yang halus, serta mempunyai keseimbangan antara protein, lemak, dan energi serta suplemen vitamin dan mineral.
\end{abstract}

\section{KATA KUNCI: bahan baku lokal, formulasi pakan}

\section{PENDAHULUAN}

Budidaya ikan dalam keramba jaring apung masih mengandalkan pasok pakan berupa ikan rucah yang dapat mencapai 60\%-70\%dari total biaya produksi. Karena itu, perlu pengadaan pakan buatan yang memenuhi persyaratan kebutuhan nutrisi bagi pembesaran ikan kerapu baik makro maupun mikro nutrien diperlukan sebagai informasi dasar dalam upaya pengembangan pakan buatan. Penggunaan ikan rucah perlu dipertimbangkan dalam budidaya ikan kerapu karena masih memberikan rasio konversi pakan yang tinggi dan kurang layak secara ekonomis (Rachmansyah et al., 2001).
Tseng \& Ho (1988) menyatakan bahwa penggunaan ikan rucah kurang layak sebagai pakan ikan kerapu, dengan beberapa alasan di antaranya: (a) dapat membawa bakteri dan penyakit pada ikan budidaya, (b) harga ikan tidak stabil dan sangat ditentukan oleh musim dan aktivitas penangkapan, (c) harga dan biaya operasional ikan rucah cukup mahal, (d) sulit dilakukan penampungan dalam jumlah besar karena dibutuhkan ruangan bersuhu dingin, dan (e) kurang ekonomis dalam transfer rantai makanan.

Survai mengenai ketersediaan bahan baku lokal telah dilakukan pada tahun1998/1999 pada 23 kabupaten di Sulawesi Selatan, sebagai salah satu upaya untuk mendapatkan beberapa bahan yang potensial untuk mensubtitusi bahan impor dalam pembuatan pakan ikan. Jenis bahan baku lokal tersebut adalah ikan rucah, rebon, kepala udang sebagai limbah cold storage, darah sebagai limbah dari tempat pemotongan hewan, limbah pabrik tapioka, limbah kelapa sawit, dan dedak halus. Hasil analisis komposisi nutrisi menunjukkan bahwa ikan rucah, rebon, kepala udang, darah, dapat mensubstitusi tepung ikan dan bungkil kedelai yang merupakan bahan baku impor. Ampas singkong, bungkil kelapa sawit, dan dedak halus dapat dijadikan sebagai sumber lemak maupun energi (Ahmad et al., 2000).

\section{BAHAN DAN PERALATAN}

Sebagian besar bahan baku lokal yang diperoleh dari sentra-sentra produksi masih berbentuk utuh seperti: ikan rucah, kepala udang, dan darah hewan. Dari masingmasing bahan ini masih membutuhkan proses tersendiri seperti ikan rucah dan kepala udang, melalui proses sebagai berikut: (1) dijemur sebelum digiling, (2) digiling tanpa menggunakan saringan, (3) setelah digiling dijemur kembali, (4) digiling dengan menggunakan saringan kasar (berdiameter $3 \mathrm{~mm}$ ), (5) dijemur kembali, (6) digiling dengan menggunakan saringan halus (berdiameter 0,5 $\mathrm{mm}$ ). Sedangkan untuk darah yang diperoleh dari tempat pemotongan hewan prosesnya sebagai berikut: (1) masukkan kedalam kantong plastik yang bervolume 0,5 liter, (2) kemudian dikukus hingga mengeras/menggumpal, (3) digiling dengan menggunakan pengilingan daging, (4) hasil gilingan dijemur kemudian digiling. Selanjutnya sama prosesnya dengan ikan rucah dan kepala udang. Sedangkan 
untuk bahan baku lainnya seperti dedak halus dan bungkil kelapa sawit hanya digiling satu kali saja dengan menggunakan saring halus (berdiameter 0,5 mm).

\section{PERALATAN}

Beberapa macam alat yang digunakan untuk membuat makanan dalam skala kecil untuk mencukupi kebutuhan sendiri antara lain alat penepung/penggiling, pengayak, timbangan, penakar (gelas ukur), pengaduk, pencampur, kompor, pengering, dan penampungan.

\section{Alat penepung dan pengayak}

Berbagai macam alat penggiling yang bisa digunakan antara lain: alat penggiling jagung dan kopi untuk menghaluskan bahan baku serta alat penggiling daging untuk mencetak pelet.

Selain alat penggiling, juga dibutuhkan penumbuk untuk menghaluskan bahan baku yang masih kasar misalnya lumpang besi, menggerus bahan-bahan kimia (tablet vitamin), dapat menggunakan mangkok porselen yang digunakan mortir beserta penggerusnya. Sebagai pelengkap alat penggiling perlu dilengkapi pengayak ukuran antara 40--360 mikron atau alat pengayak kopi.

\section{Timbangan dan penakar}

Timbangan yang digunakan adalah timbangan kue dengan skala maksimum $5 \mathrm{~kg}$, atau timbangan beras (timbangan watangan) apabila bahan jumlahnya besar setiap bagian dalam suatu susunan ramuan. Sedangkan bahan yang jumlahnya sangat kecil, dibutuhkan timbangan analitik.

Untuk menakar bahan-bahan yang berbentuk cair diperlukan beberapa macam alat penakar di antaranya: jarum suntik atau pipet untuk jumlah sedikit (hanya beberapa mililiter), untuk jumlah yang lebih banyak

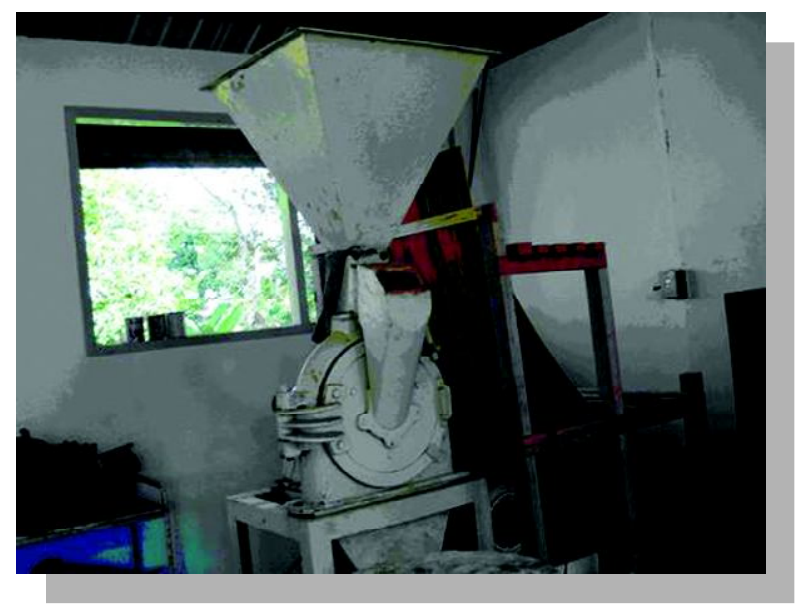

Gambar 1. Alat penepung digunakan gelas ukur (berbagai macam ukuran), selain itu dapat juga digunakan gayung yang ukurannya juga bermacam-macam.

\section{Alat pengaduk dan pencampur}

Pengaduk dan pencampur bisa digunakan mixer apabila ada listrik, sendok plastik (sendok nasi), baskom yang dimasukkan ke dalam kantong plastik lalu dikocok. Pencampuran bahan-bahan yang berupa tepung kering dimulai dari bahan yang jumlahnya sangat sedikit, kemudian secara berangsur-angsur tambahkan sebagian bahan-bahan lain yang jumlahnya lebih banyak, bahan yang jumlahnya paling banyak dicampurkan terakhir supaya pencampurannya lebih merata.

Masukkan bahan basah atau cair berupa minyak ikan dan minyak kedelai sedikit demi sedikit sambil diaduk hingga merata. Siram air hangat sebanyak $40 \%$ sambil diaduk hingga merata atau sampai bisa menggumpal dan mudah terhambur, kemudian dicetak dengan alat penggiling daging. Besar kecilnya pelet tergantung pada ukuran lubang dais pencetaknya, kepadatan pelet ditentukan oleh tingkat kehalusan bahan baku serta bahan perekatnya.

\section{PEMILIHAN BAHAN BAKU}

Mujidman (1989) mengatakan dalam penyusunan ramuan pakan ikan perlu diperhatikan tentang pemilihan bahannya. Bahan tersebut harus memenuhi persyaratan sebagai berikut: (1) mempunyai nilai gizi tinggi, (2) mudah diperoleh, (3) mudah diolah, (4) harganya relatif murah, dan (5) tidak merupakan makanan pokok manusia, sehingga tidak merupakan saingan.

Untuk mengetahui nilai gizi dari masing-masing bahan baku dilakukan analisis di laboratorium (proksimat). Ahmad et al. (2000) mengatakan ada beberapa jenis bahan

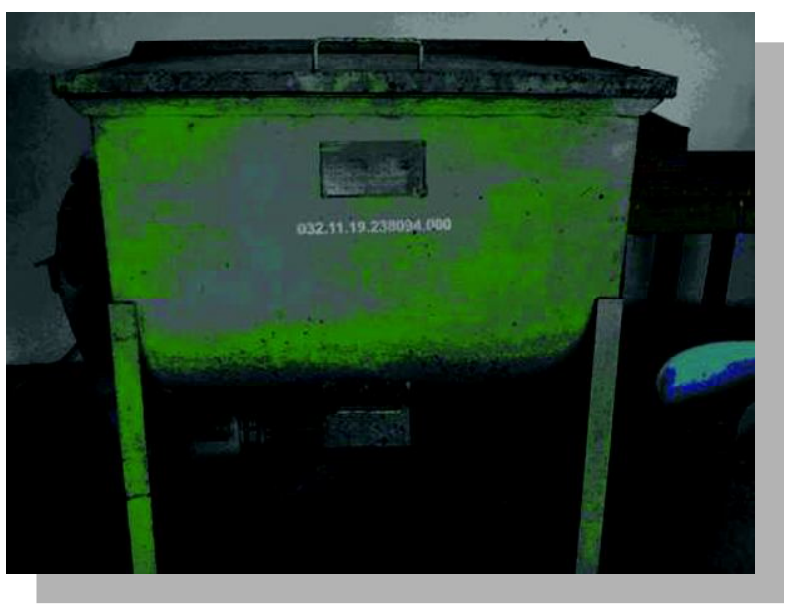

Gambar 2. Mesin pencampur 


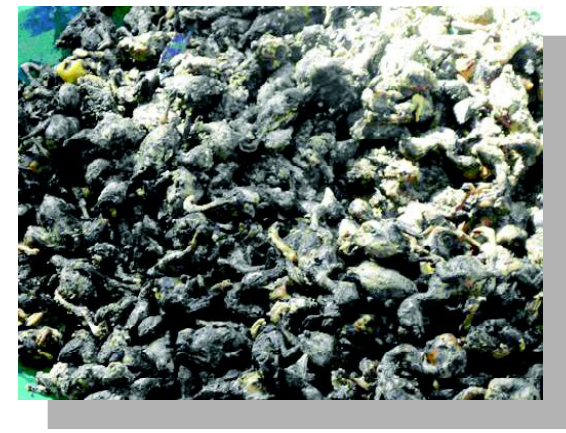

Gambar 3. Bahan baku anak ayam

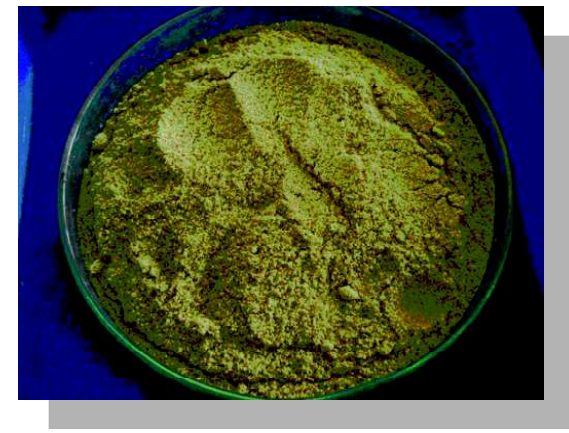

Gambar 4. Tepung telur ikan

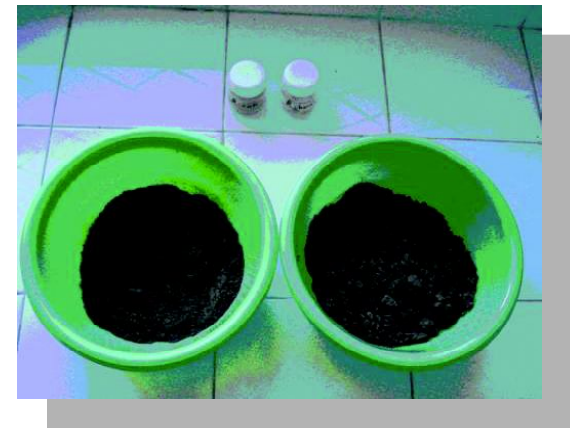

Gambar 5. Bungkil kelapa kopra baku lokal dari hasil analisis komposisi nutrisi menunjukkan bahwa ikan rucah, rebon, kepala udang, darah dapat mensubtitusi tepung ikan dan bungkil kedelai yang merupakan bahan baku impor. Ampas singkong bungkil kelapa sawit dan dedak halus dapat dijadikan sebagai sumber lemak maupun energi. Penyusunan ramuanfformulasi dapat diperhitungkan bagian-bagiannya berdasarkan kadar zat-zat dari masing-masing bahan baku yang akan digunakan. Nilai kecernaan protein dari bahan baku sumber hewani dan nabati cukup tinggi antara $67,2 \%$ 92,5\% kecuali tepung darah dan dedak masing-masing $55,2 \%$ dan 59,5\% melihat daftar komposisi bahan baku yang telah dilakukan oleh para peneliti (Mujidman, 1989).

\section{PERSIAPAN BAHAN}

Bahan baku yang akan digunakan untuk menyusun formulasi pakan ikan, yang terlebih dahulu dilihat adalah kualitasnya yang dapat diketahui secara sepintas melalui komposisi bahan baku serta kandungan nutrisi selama masa penyimpanan, seperti tidak berjamur, bau tidak tengik, dan kehalusan butirannya. Hal ini penting karena kehalusan bahan mempengaruhi kepadatan pakan (ketahanan pakan dalam air). Untuk menghindari terjadinya kesalahan dalam penimbangan bahan, maka bahan yang akan ditimbang diurut mulai dari bahan yang terkecil hingga bahan yang paling banyak dibutuhkan.

\section{FORMULASI PAKAN}

Beberapa bahan baku pakan lokal diperoleh di sentrasentra produksi di Sulawesi Selatan yaitu tepung ikan lokal, tepung rebon, tepung kepala udang, tepung darah, tepung kedelai, dan dedak halus, kecuali wheat gluten serta pati jagung yang dipakai dalam formulasi pakan ikan kerapu. Menyusun formulasi pakan, terlebih dahulu ditentukan bahan baku yang dipakai untuk pakan, umur ikan, jenis ikan, dan ukuran ikan, baru penentuan kandungan protein pakan yang akan dibuat, misalnya formulasi pakan pembesaran ikan kerapu dengan kandungan protein $49 \%$ Bahan terdiri atas 50\%tepung ikan, $11 \%$ tepung kedelai, $8 \%$ wheat gluten, $8 \%$ tepung rebon, $6 \%$ dedak halus, $7 \%$ pati jagung, $4 \%$ minyak ikan, $2 \%$ minyak kedelai, $2 \%$ vitamin, $2 \%$ mineral, dan vitamin C $150 \mathrm{mg} / \mathrm{kg}$ pakan. Kemudian dihitung kadar protein masing-masing bagian sebagai berikut:

Tabel 1. Komposisi nutrisi (\% beberapa bahan baku pakan lokal di Sulawesi Selatan

\begin{tabular}{lcccccc}
\hline \multicolumn{1}{c}{ Bahan baku } & $\begin{array}{c}\text { Kadar air } \\
\mathbf{( \% )}\end{array}$ & $\begin{array}{c}\text { Protein } \\
\mathbf{( \% )}\end{array}$ & $\begin{array}{c}\text { Lemak } \\
\mathbf{( \% )}\end{array}$ & $\begin{array}{c}\text { Serat kasar } \\
\mathbf{( \% )}\end{array}$ & $\begin{array}{c}\text { Abu } \\
\mathbf{( \% )}\end{array}$ & $\begin{array}{c}\text { Energi } \\
\mathbf{( k a l . / g )}\end{array}$ \\
\hline Tepung kepala udang & 6,3 & 49,8 & 3,8 & 2 & 25,1 & 3,257 \\
Tepung rebon & 7,3 & 52,6 & 1,1 & 1,8 & 14,7 & 2,500 \\
Tepung ikan rucah & 7,7 & 65,2 & 4,8 & 1,8 & 12,6 & 4,146 \\
Tepung ikan & 7 & 44,7 & 9,9 & 3,4 & 24,7 & 4,242 \\
Tepung darah & 3,2 & 84,3 & 0,2 & 6,2 & 3,6 & 4,844 \\
Tepung kedelai & 9,3 & 41 & 18,2 & 7,2 & 6 & 4,310 \\
Bungkil kelapa sawit & 8,3 & 10,6 & 12,7 & 31,8 & 4,4 & 3,767 \\
Dedak halus & 7,7 & 13,8 & 11,9 & 14,3 & 10,5 & 3,141 \\
Pati jagung & 0,7 & 11,25 & 0,64 & 2,62 & 2,97 & \\
\hline
\end{tabular}

Sumber: Ahmad et al. (2000) 
- Kadar protein dari 50\%tepung ikan $=50 \times(65,2: 100)$ $=32,6 \%$

- Kadar protein dari 11\%tepung kedelai $=11 \times(41,0$ : $100)=4,5 \%$

- Kadar protein dari $8 \%$ wheat gluten $=8 \times(85,5: 100)$ $=6,84 \%$

- kadar protein dari 8\%tepung rebon $=8 \times(52,6: 100)$ $=4,20 \%$

- kadar protein dari $6 \%$ dedak halus $=6 \times(13,8: 100)$ $=0,83 \%$

- kadar protein dari 7\%pati jagung $=7 \times(11,25: 100)$ $=0,79 \%$

Salah satu contoh dalam menyusun formulasi pakan, apabila kadar protein tersebut dijumlahkan, maka didapatkan nilai 49,76\% meskipun nilai yang diperoleh dari perhitungan di atas memperlihatkan selisih 0,76\% dari total protein pakan yang diinginkan. Untuk memperhitungkan kadar zat-zat gizi lainnya, seperti lemak, karbohidrat, dan lain-lain, dapat dilakukan seperti halnya menghitung kadar protein. Jadi tentukan kadar zat gizi dari masing-masing bagian bahan yang akan dipakai, baru kemudian jumlahkan.
Beberapa bahan baku lokal yang telah dimanfaatkan untuk mengurangi penggunaan tepung ikan dalam pembesaran ikan di keramba di antaranya keong mas (Usman et al., 2006) melaporkan bahwa tepung keong mas dapat digunakan hingga 30\%dalam formulasi pakan untuk mensubtitusi tepung ikan sebagai sumber protein (setara $46,1 \%$ protein tepung ikan) dalam pakan pembesaran ikan kerapu macan. Sedangkan Rachmansyah et al. (2001) pemanfaatan tepung kepala udang sebagai bahan subtitusi tepung ikan dalam pakan pembesaran ikan kerapu bebek, Cromileptes altivelis dapat digunakan sebanyak 10\% Kamaruddin \& Usman (2006) melaporkan kecernaan bahan kering tepung DOC pada ikan kerapu macan di keramba jaring apung sekitar $88,2 \%$ kecernaan protein sekitar $73,7 \%$ dan kecernaan lemak sekitar $70 \%$ Hasil tersebut menunjukkan bahwa tepung DOC berpeluang dimanfaatkan untuk mengurangi penggunaan tepung ikan sebagai sumber protein dalam pakan ikan kerapu macan. Kabangnga et al. (2005), melaporkan bahwa penambahan tepung DOC sebanyak 50\% dapat memberikan respons pertumbuhan dan pertambahan lebar karapas kepiting bakau sama dengan kontrol. Hal ini disebabkan karena komposisi asam amino tepung DOC hampir sama dengan tepung ikan (Tabel 2).

Tabel 2. Komposisi asam amino tepung DOC

\begin{tabular}{|c|c|c|c|}
\hline \multirow{2}{*}{ Asam amino } & \multirow{2}{*}{ Kode } & \multicolumn{2}{|c|}{ Kandungan $(\%)$} \\
\hline & & Tepung ikan & Tepung DOC \\
\hline Aspartat & ASP & 5,105 & 4,768 \\
\hline Threonin & THR & 2,430 & 2,361 \\
\hline Serin & SER & 2,034 & 2,379 \\
\hline Glutamat & GLU & 8,722 & 9,368 \\
\hline Glysin & GLY & 3,391 & 5,227 \\
\hline Alanin & ALA & 3,382 & 3,891 \\
\hline Cystein & CYS & 0,516 & 0,187 \\
\hline Valin & VAL & 2,584 & 3,081 \\
\hline M ethionin & MET & 1,495 & 0,062 \\
\hline Isoleusin & ILE & 2,208 & 2,405 \\
\hline Leusin & LEU & 4,004 & 4,260 \\
\hline Tyrosin & TYR & 1,796 & 1,639 \\
\hline Phenilalanin & PHE & 2,485 & 1,965 \\
\hline Hydroksi-Lysin & HYLYS & 0,137 & 0,515 \\
\hline Lysin & LYS & 4,222 & 3,889 \\
\hline Histidin & HIS & 1,524 & 1,212 \\
\hline Arginin & ARG & 3,064 & 4,058 \\
\hline Hydroksi-Prolin & HYPRO & 0,591 & 1,376 \\
\hline Prolin & PRO & 2,106 & 3,620 \\
\hline Jumlah (Protein) & & 51,795 & 56,281 \\
\hline
\end{tabular}


Selain itu, tepung usus ayam juga telah dicoba untuk mensubstitusi tepung ikan dalam pakan ikan kerapu macan seperti yang dilakukan oleh Usman et al. (2006) melaporkan bahwa pemanfaatan tepung silase usus ayam sebanyak $20 \%$ dalam pakan ikan kerapu macan, memberikan pertumbuhan yang sama dengan pakan kontrol (tanpa tepung silase usus ayam), dengan penggunaan usus ayam dapat mengurangi penggunaan tepung ikan dalam pakan sebanyak $20 \%$

Semua formulasi tersebut menunjukkan hasil yang tidak beda nyata dengan kontrol terhadap pertumbuhan hewan uji yang digunakan (ikan).

Kandungan asam amino usus ayam adalah sebagai berikut:

\begin{tabular}{llllll}
\hline Aspartat & $: 5,85$ & Threonin & $: 2,629$ & Serine & $: 2,629$ \\
Glutamat & $: 10,947$ & Glysine & $: 3,947$ & Alanine & $: 3,947$ \\
Cystein & $: 0,405$ & Valine & $: 2,750$ & Methionine & $:$ \\
Isoleusine & $: 2,263$ & Leucine & $: 4,435$ & Tyrosine & $: 0,691$ \\
Phenilalanine & $: 2,036$ & Hydroksilysine $: 0,198$ & Lysine & $: 3,240$ \\
Histidine & $: 0,829$ & Arginine & $: 4,712$ & Hydroksiprolin : 0,952 \\
Prolin & $: 2,571$ & $\mathrm{NH}_{3}$ & $: 2,192$ & & \\
\hline
\end{tabular}

Sumber: Hartadi et al. (1993)

Tabel 3. Beberapa jenis formulasi pakan moist pellet $(A, B, C, D, E)$ dan pelet kering $(F, G)$ dengan menggunakan beberapa bahan baku lokal dalam pembesaran ikan kerapu macan, Epinephelus fuscoguttatus dan kepiting bakau, Scylla serrata di keramba jaring apung

\begin{tabular}{|c|c|c|c|c|c|c|c|}
\hline \multirow{2}{*}{ Bahan } & \multicolumn{7}{|c|}{ Beberapa jenis formulasi pakan (\%kering) } \\
\hline & A & B & C & D & $\mathbf{E}$ & $\mathbf{F}$ & G \\
\hline Ikan rucah (kadar air 75\% & 50 & 74 & 80 & 75 & 74 & - & - \\
\hline Tepung ikan & 49 & 15,6 & 50 & 18,25 & 28,5 & 50 & 5 \\
\hline Dedak halus & 9 & 3 & - & - & 4 & 5 & - \\
\hline Tepung terigu & 8,5 & 5,9 & 11,9 & 8,5 & 16 & 5 & 10 \\
\hline Tepung kedelai & 7 & 6 & - & 7 & - & 16 & 7,5 \\
\hline Tepung keong mas & - & 30 & - & - & - & - & - \\
\hline Tepung kepala udang & - & - & 9 & - & 9 & - & 6 \\
\hline Tepung hati cumi & - & - & - & 7 & - & - & - \\
\hline Tepung gluten & - & - & - & - & - & 7 & - \\
\hline Tepung rebon & - & - & - & 7 & 20 & 7 & 4 \\
\hline Tepung silase usus ayam & - & - & - & 20 & - & - & - \\
\hline Tepung kanji & - & - & - & - & - & - & 11,5 \\
\hline Tepung anak ayam (DOC) & - & - & - & - & - & - & 50 \\
\hline M inyak ikan & 2 & 5,5 & 3 & 4 & 3 & 4 & 2 \\
\hline M inyak jagung & - & - & - & - & - & - & 1 \\
\hline M inyak kedelai & 1 & 2 & 1,5 & 2 & 2 & 2 & - \\
\hline Mineral mix & 1 & 3 & 1,5 & 2 & 1 & 1,5 & 1 \\
\hline Vitamin mix & 2 & 1,5 & 3 & 1 & 3 & 2,5 & 2 \\
\hline Carophyll pink & - & - & 0,08 & - & - & - & - \\
\hline Sellulosa & - & - & - & 4 & - & - & - \\
\hline Vitamin C (APNa) & - & - & - & - & - & 0,015 & - \\
\hline Ronozyme $\mathrm{P}$ & - & - & - & - & - & 0,1 & - \\
\hline Total & 137,5 & 148 & 159,9 & 155,8 & 160,5 & 100 & 100 \\
\hline
\end{tabular}


Tabel 4. Komposisi nutrisi dari formulasi pakan moist pellet $(A, B, C, D, E)$ dan pelet kering $(\mathrm{F}, \mathrm{G})$

\begin{tabular}{lccccccc}
\hline \multirow{2}{*}{$\begin{array}{c}\text { Komposisi nutrisinya } \\
\text { (\%kering) }\end{array}$} & A & B & C & D & E & F & G \\
\cline { 2 - 7 } & 46,6 & 45,7 & 46,7 & 45,81 & 46,5 & 48,13 & 37,5 \\
\hline Protein kasar & 6,2 & 11,7 & 12,6 & 13,13 & 10,8 & 12,33 & 7,51 \\
Lemak kasar & 3,4 & 2 & 3,8 & 3,86 & 3 & 2,99 & 7,94 \\
Serat kasar & 17,4 & 14 & 13 & 12,14 & 14,8 & 13,71 & 10,09 \\
Kadar abu & 26,4 & 26,6 & 23,9 & 25,06 & 24,9 & 22,82 & 36,96 \\
BETN &
\end{tabular}

a Vitamin mix (g/kg of mix): terdiri atas: vit. A 60.000 .000 IU; vit. D3 12.000 .000 IU; vit. E 120.000 mg; vit. K3 12.500 mg; vit. B1 10.000 mg; vit. B2 25.000 mg; vit. B6 10.000 mg; vit. B12 $100 \mathrm{mg}$; vit. C $150.000 \mathrm{mg}$; folic acid $5.000 \mathrm{mg}$; nicotinic acid, $60.000 \mathrm{mg}$; D-panthotenic acid, $50.000 \mathrm{mg}$; biotin, $125 \mathrm{mg}$; D/L-methionine, $50.000 \mathrm{mg}$.

b Mineral mix (g/kg of mix) terdiri atas: calcium 32,5\% phospor $107 \% \mathrm{Fe} 6 \mathrm{~g}$; $\mathrm{Mn} 4 \mathrm{~g}$; iodine 0.075 g; Cu 0.3 g; Zn 3.75 g; vit. B12 0.5 mg; vit D3 50.000 IU

Keterangan:

A. Formulasi pakan kontrol, B. Formulasi pemanfaatan keong mas untuk mensubstitusi tepung ikan, C. Formulasi dengan perlakuan penambahan Caroohill pink, D. Formulasi pakan substitusi tepung usus ayam dalam pakan, E. Formulasi pakan dengan pemanfaatan tepung rebon, F. Formulasi pakan penggunaan tepung ikan lokal, melalui penambahan vitamin C (APNa) dan Ronozyme dalam pakan, dan G. Formulasi pakan dengan memanfaatkan tepung anak ayam (DOC) dalam pakan kepiting bakau.

Sumber: Laporan hasil penelitian Balai Riset Perikanan Budidaya Air Payau Maros dari tahun 2001 sampai 2006

Tabel 5. Nilai kecernaan (\% bahan kering protein dan energi beberapa bahan baku lokal pakan pembesaran ikan kerapu bebek

\begin{tabular}{lccc}
\hline \multicolumn{1}{c}{ Bahan baku lokal } & Bahan kering & Protein & Energi \\
\hline Tepung kepala udang & 45,3 & 78,0 & 63,6 \\
Tepung kedelai & 58,5 & 67,2 & 51,1 \\
Bungkil kelapa sawit & 54,8 & 80,5 & 40,4 \\
Tepung darah & 38,1 & 55,2 & nd \\
Silase darah (asam formiat 3\% & 66,5 & 87,5 & nd \\
Silase darah (asam fropionat 3\% & 51,3 & 84,2 & nd \\
Tepung ikan tembang & 86,4 & 93,0 & 85,2 \\
Tepung ikan komersil & 59,5 & 82,4 & 77,3 \\
Dedak halus & 22,7 & 59,5 & 44,3 \\
\hline
\end{tabular}

nd: tidak dapat dianalisis

Sumber: Laining \& Rachmansyah (2002)

Sebagian besar bahan yang digunakan adalah bahan baku lokal seperti tepung ikan rucah, tepung rebon, tepung kedelai, dan dedak halus di mana nilai kecernaan protein dari semua bahan baku relatif tinggi $(>67 \%)$ kecuali dedak halus $(<60 \%$ ). Bahan baku sumber hewani nilai kecernaan energi dan bahan keringnya lebih tinggi dibandingkan bahan nabati (Laining et al., 2001).

\section{KESIMPULAN}

Dalam persiapan bahan baku lokal untuk pakan ikan membutuhkan beberapa proses pengolahan seperti: penepungan, analisis kandungan nutrisi, dan perhitungan formulasi pakan, untuk memperoleh pelet yang berkualitas dan harus ditunjang struktur bahan yang halus. Hal ini disebabkan bahan baku sebagian besar masih dalam bentuk utuh. Pada umumnya bahan baku lokal tersebut mempunyai kandungan nutrisi yang cukup untuk mensubstitusi bahan baku impor seperti bungkil kedelai dan tepung ikan. Selain itu, bahan baku lokal dapat mengurangi penggunaan tepung ikan sebagai sumber protein hewani seperti keong mas, tepung anak ayam, rebon, dan tepung usus ayam. 


\section{DAFTAR PUSTAKA}

Ahmad, T., Rachmansyah, and N.N. Palinggi. 2000. The availability and use of fish feed local ingredients for humpback grouper grow-out. Proceeding of Regional Workshop on Managemen Strategies for Sustainable Sea Farming and Grouper. Aquaculture. NACA, Bangkok, Thailand. p. 90- 120.

Hartadi, H., S. Reksohadiprojo, dan D.T. Allen. 1993. Tabel komposisi pakan untuk Indonesia. Gadjah Mada University Press., Yogyakarta. 145 pp.

Kabangnga, N., Usman, Kamaruddin, dan N.N. Palinggi. 2005. Substitusi tepung ikan dengan DOC dalam pakan pembesaran kepiting bakau di keramba jaring apung. Laporan Hasil Penelitian Balai Riset Perikanan Budidaya Air Payau. Maros Sulawesi Selatan. 12 pp.

Kamaruddin dan Usman. 2006. Uji kecernaan beberapa bahan baku pakan pada ikan kerapu macan, Epinephelus fuscoguttatus di keramba jaring apung di laut. Laporan Hasil Penelitian Balai Riset Perikanan Budidaya Air Payau Maros, Sulawesi Selatan. 13 pp.

Mujidman, A. 1989. Ramuan makanan ikan. Penebar Swadaya Jakarta.
Laining, A., Rachmansyah, and T. Ahmad. 2001. Shrimp head meal as a substitute of fish meal in grower feed for barramundi cod, Cromileptes altivelis. Aquaculture Asia, VI(2): 31- 32.

Laining, A. dan Rachmansyah. 2002. Komposisi nutrisi beberapa bahan baku lokal dan nilai kecernaan proteinnya pada ikan kerapu bebek, Cromileptes altivelis. J. Pen. Per. Indonesia edisi Akuakultur, 8(2): 45- 51.

Rachmansyah, P.R. Pong-Masak, A. Laining, dan A.G. Mangawe. 2001. Kebutuhan protein pakan bagi pembesaran ikan kerapu bebek, Cromileptes altivelis. J. Pen. Perik. Indonesia. 7(4): 40-45.

Tseng, W.Y. and S.K. Ho. 1988. The biology and culture of red grouper. Mu-Shiung Chang. Chieng Cheng Publisher. Kaohsiung, R.O.C. 134 pp.

Usman, Rachmansyah, dan Kamaruddin. 2006. Substitusi tepung ikan dengan tepung keong mas, Pomacea sp. dalam pakan pembesaran ikan kerapu Macan Epinephelus fuscoguttatus. J. Ris. Akuakultur. 